\title{
Modification of soil properties by Prosopis L. in the Kalahari Desert, South-Western Botswana
}

\author{
Samuel Mosweu ${ }^{1^{*}}$, Christopher Munyati $^{2}$, Tibangayuka Kabanda $^{2}$ \\ ${ }^{1}$ Department of Environmental Science, University of Botswana, Gaborone, Botswana; \\ *Corresponding Author: mosweu@mopipi.ub.bw \\ ${ }^{2}$ Department of Geography and Environmental Science, North-West University, Mafikeng Campus, Mafikeng, South Africa
}

Received 15 December 2012; revised 16 January 2013; accepted 14 February 2013

Copyright (C) 2013 Samuel Mosweu et al. This is an open access article distributed under the Creative Commons Attribution License, which permits unrestricted use, distribution, and reproduction in any medium, provided the original work is properly cited.

\begin{abstract}
The aim of this research was to investigate the interactions between Prosopis plants and soils in the Kalahari area, south west of Botswana. The underlying assumptions of the research were that Prosopis plants significantly enhanced the nutrient content and improved the condition of soils in the study area, and that the height and canopy size of Prosopis plants affected the interactions between Prosopis plants and the soils. Firstly, soil samples were collected under 42 randomly selected Prosopis plant canopies and in the spaces between Prosopis plant canopies at the depth of $0-20 \mathrm{~cm}$ and $60-80 \mathrm{~cm}$. Secondly, soil samples were collected under 45 randomly selected Prosopis plant canopies of three different categories of height and canopy size at the depth of $0-10 \mathrm{~cm}$. The soil samples were analysed for soil organic carbon, pH, total nitrogen (N), electrical conductivity (EC), calcium (Ca), sodium (Na), potassium $(\mathrm{K})$, and magnesium (Mg). Soil collected under Prosopis plant canopies and in the spaces between Prosopis plant canopies showed statistically significant difference in the soil organic carbon content $(F=2.68, P=0.05, \alpha=0.05), \mathrm{pH}$ $(F=44.81, P<0.001 ; \alpha=0.05)$ and electrical conductivity $(E C)(F=3.75, P=0.01, \alpha=0.05)$. Statistically significant difference was also observed in the comparison of soils existing under Classes 1, 2 and 3 Prosopis plant canopies in relation to $\mathrm{pH}$ and EC $(F=6.56, P=0.01$ and $F=$ 4.77, $P=0.01$ respectively at $\alpha=0.05$ ). Therefore, it was concluded that the fundamental assumptions of the study were valid.
\end{abstract}

Keywords: Prosopis Species; Soil Properties;
Kalahari Desert; Botswana

\section{INTRODUCTION}

Prosopis Linnaeus amended Burkart genus belongs to the family Leguminosae (Fabaceae), sub-family Mimosoideae [1]. The genus range covers arid and semi-arid regions in Africa, Asia, Central, Northern and Southern regions of America [1]. The best known and most widely spread Prosopis species is Prosopis juliflora [1]. [2] described Prosopis species as trees or shrubs of various sizes which are primarily xerophilous, aculeate, and spiny. The taxonomy of the Prosopis genus compiled by [2] included 44 Prosopis species and a number of varieties. The species are aggressive pioneers which predominate over other flora wherever they are introduced [1]. They are famous for their rapid growth and their resilience under harsh arid and semi-arid environments [1]. They also have the capacity to assimilate and store nutrients and moisture in their root systems. Consequently, they usually have relatively large root mass [3]. Since their introduction in Africa, they have aggressively invaded and continue to invade large areas of rangelands [1]. The rangelands in the south east of Botswana are amongst the areas that are seriously affected by the invasion of Prosopis species.

Previous studies on the interactions between Prosopis species and soil indicated that leguminous tree species modify the characteristics of soil on which they grow $[4,5]$. Elevated soil nutrient content and lower values of $\mathrm{pH}$ are generally associated with soils found under canopies of Prosopis plants compared to the inter-canopy areas in arid and semi-arid environments $[1,4,5]$. Empirical research has shown that the size of a tree, particularly canopy cover, may affect the condition of soil under tree canopy [6,7]. For instance, at earlier stages when a tree is young and its canopy size is small, organic matter may not be efficiently trapped under a small tree canopy 
within a relatively short period of time $[8,9]$. With advancing developmental stage of an individual tree, the canopy size and duration of nutrient accumulation may increase, leading to the improvement in understory soil conditions $[8,9]$. Therefore, this research aims to investigate the interactions between Prosopis plants and soils in the Kalahari area, south west of Botswana. The research specifically tests the assumptions that Prosopis plants significantly enhance the nutrient content and improve the condition of soils in the Kalahari area and that the height and canopy size of Prosopis plant affect the interactions between Prosopis plants and the soils.

\section{MATERIALS AND METHODS}

\subsection{Description of the Study Area}

The study focuses on four villages (Bokspits, Rappelspan, Vaalhoek and Struizendam) located in the Kalahari district in Botswana (Figure 1). The area lies within the Kalahari Desert; a vast area covered in sand stretching between the Orange River and the Zambezi River covering the western and central part of Botswana, eastern Namibia and North western regions of South Africa. The area is mainly undulating plains with interspersed pans, rocky outcrops, dry river valleys and dune fields [10]. It is dominated by longitudinal dunes and some barchan or transverse dunes [11].

It is generally believed that the Nossob-Molopo River valley that exists in the area was part of the Orange River system [10]. The sand stone and quartz comprise the rocky outcrops in the study area with calcrete dominating the riparian zones along the Nossob-Molopo River. The area is also characterized by ephemeral and often relict closed basins of varying scales and origin [12] called pans. The vegetation of the area is generally open tree and grass savanna with sparse cover of tussock grasses. Acacia erioloba, Acacia haematoxylon, Rhigozum trichotomum, Lycium namaquense, Monechma incanum, Prosopis chilensis, Prosopis velutina, Prosopis juliflora, Prosopis glandulosa, hybrids of $P$. juliflora and $P$. glandulosa, P. Juliflora and P. pallida, P. chilensis and $P$. glandulosa, P. glandulosa and P. pallida, and P. juliflora and Acacia karoo comprise the main trees and shrubs found in the study area [13] while Schmidtia pappophoroides, and Eragrostis species are the main grass species growing in the area [10].

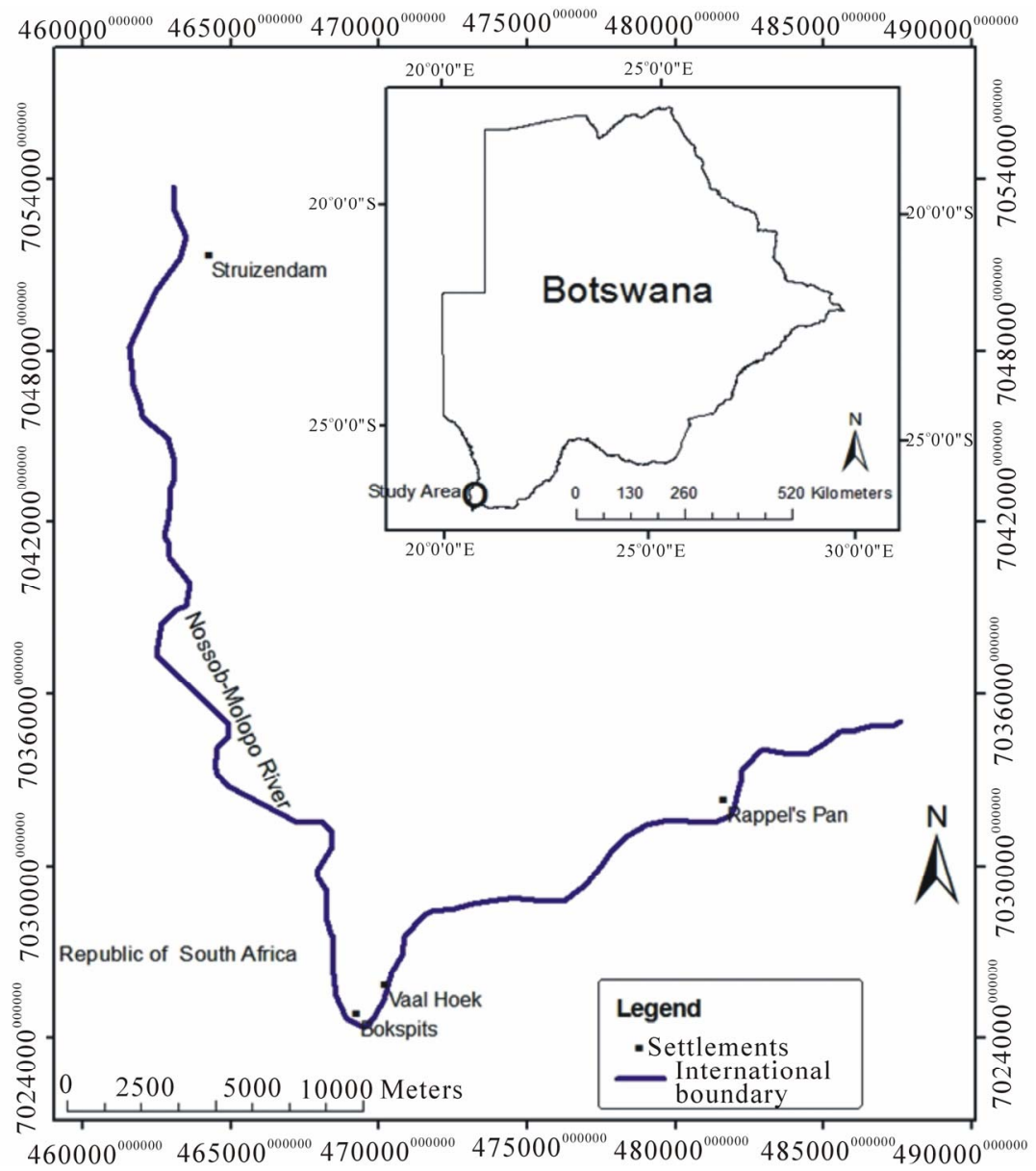

Figure 1. Location of the study area. 
The study area forms part of the driest region of Botswana where the mean annual rainfall is $300 \mathrm{~mm}$ and the rainfall season is characterized by erratic rainfall pattern [14]. The period starting from November to April marks the season during which the area experiences about 80 per cent of the precipitation. The area experiences very high temperatures in summer which may reach up to over $40^{\circ} \mathrm{C}$, while the winter temperatures are normally between 2 to $4^{\circ} \mathrm{C}$ [10].

\subsection{Experimental Design and Laboratory Analyses}

Firstly, soil samples were collected along three transects spaced equally and radiating from the main stem of 42 randomly selected mature $\left(\geq 2.5 \mathrm{~m}\right.$ height and $\geq 20 \mathrm{~m}^{2}$ canopy cover) Prosopis tree. Using an auger, soil cores of $5 \mathrm{~cm}$ in diameter and $20 \mathrm{~cm}$ in length were obtained: 1) under plant canopy or crown at $0.5 \mathrm{~m}$ of the radius of the plant canopy and 2) in the space between plant canopy (inter-space/inter-canopy) at a distance of $150 \mathrm{~m}$ from the nearest Prosopis plants to reduce the influence of Prosopis plants on the inter-canopy soil samples. A total of 504 soil samples were collected at the depth of $0-20$ $\mathrm{cm}$ and $60-80 \mathrm{~cm}$ and pooled by depth and location resulting in a total of 168 soil samples which were prepared for laboratory analysis.

Secondly, Prosopis plants were categorized into three classes (i.e. Class 1: 0.3-1.5 $\mathrm{m}$ height and 1-9 $\mathrm{m}^{2}$ canopy cover; Class 2: 1.6-2.5 m height and 10-19 $\mathrm{m}^{2}$ canopy cover; Class $3: 2.5+\mathrm{m}$ height and $20+\mathrm{m}^{2}$ canopy cover). Soil samples were then collected along three transects spaced equally and radiating from the main stem of 45 randomly selected Prosopis plants (15 per class) at $20 \mathrm{~cm}$ distance from the stem under plant canopy. The depth of sampling was $0-10 \mathrm{~cm}$ and sampling was conducted by the use of a hand trowel. A total of 270 soils samples was collected and pooled according to sampling location to make 90 composite samples for laboratory analysis.

All soil samples were prepared by air-drying and sieving through a $2 \mathrm{~mm}$ mesh sieve to remove plant material. The soil samples were analyzed for total nitrogen (N), soil organic carbon, $\mathrm{pH}$, electrical conductivity (EC), exchangeable cations (calcium $(\mathrm{Ca})$, sodium $(\mathrm{Na})$, potassium $(\mathrm{K})$, and magnesium $(\mathrm{Mg})$ ) as outlined below.

- Total nitrogen and organic carbon were determined using the LecoTruspec $\mathrm{CN}$ instrument.

- Soil pH and electrical conductivity (EC) were investigated using the 1:2 (soil: water) ratio extract method [15]. The $\mathrm{pH}$ meter was used to measure soil $\mathrm{pH}$ and the electrical conductivity meter was used to measure soil EC.

- $\mathrm{Ca}, \mathrm{Mg}, \mathrm{K}$ and $\mathrm{Na}$ were analysed through the silver thiourea method [16] and the Varian 220 FS Atomic Absorption Spectrophotometer (AAS).

\section{RESULTS}

The mean values of the selected soil properties were determined and presented in Tables 1 and 2. Analysis of Variance (one way ANOVA) showed that soil organic carbon at $0-20 \mathrm{~cm}$ under canopy, $60-80 \mathrm{~cm}$ under canopy, 0 - $20 \mathrm{~cm}$ inter-canopy and $60-80 \mathrm{~cm}$ inter-canopy soil depths were statistically significantly different $(F=2.68, P=0.05, \alpha=0.05)$. Student's t-Test (one tailed) indicated that soil at $0-20 \mathrm{~cm}$ depth had statistically significantly lower soil organic carbon content in comparison with soil at $60-80 \mathrm{~cm}$ depth under Prosopis plant canopies (Table 3). Additionally, soil at 0 - $20 \mathrm{~cm}$ depth in the inter-canopy had statistically significantly lower soil organic carbon compared to soil at $60-80 \mathrm{~cm}$ under canopy and $60-80 \mathrm{~cm}$ inter-canopy depth. Generally soil organic carbon at $0-20 \mathrm{~cm}$ depth was statistically significantly lower than at $60-80 \mathrm{~cm}$ depth.

It was observed through Analysis of Variance (one way ANOVA) that soil $\mathrm{pH}$ differed significantly $(F=$ $44.81, P<0.001 ; \alpha=0.05)$ at $0-20 \mathrm{~cm}$ under canopy, 60 - $80 \mathrm{~cm}$ under canopy, 0 - $20 \mathrm{~cm}$ inter-canopy and $60-80$ cm inter-canopy soil depths. Student's t-Test (one tailed) showed that soil $\mathrm{pH}$ was significantly lower at $0-20 \mathrm{~cm}$ under canopy depth in comparison with $60-80 \mathrm{~cm}$ under canopy, $0-20 \mathrm{~cm}$ inter-canopy and $60-80 \mathrm{~cm}$ inter-canopy depths (Table 3 ). The soil $\mathrm{pH}$ was also significantly lower at $0-20 \mathrm{~cm}$ inter-canopy compared to $60-80 \mathrm{~cm}$ under canopy and $60-80 \mathrm{~cm}$ inter-canopy soil depths. The general pattern in the soil $\mathrm{pH}$ showed lower $\mathrm{pH}$ levels at $0-20 \mathrm{~cm}$ soil depth as compared to 60 - $80 \mathrm{~cm}$ soil depth (Table 3). The observed values were above $\mathrm{pH} 7$, indicating that the soils in the study area were generally basic.

Analysis of Variance (one way ANOVA) revealed statistically significant difference $(F=3.75, P=0.01, \alpha=$ 0.05 ) in the soil electrical conductivity (EC) at $0-20 \mathrm{~cm}$ under canopy, $60-80 \mathrm{~cm}$ under canopy, $0-20 \mathrm{~cm}$ inter-canopy and $60-80 \mathrm{~cm}$ inter-canopy depths. Student's t-Test (one tailed) showed that soil EC was significantly higher at $0-20 \mathrm{~cm}$ under canopy depth compared to 60 $80 \mathrm{~cm}$ under canopy, $0-20 \mathrm{~cm}$ inter-canopy and 60-80 $\mathrm{cm}$ inter-canopy depths (Table 3). In addition, soil had significantly higher EC $(P \leq 0.001, \alpha=0.05)$ at $0-20$ $\mathrm{cm}$ depth under Prosopis plant canopies. The content of soil $\mathrm{Ca}, \mathrm{Mg}, \mathrm{K}$ and $\mathrm{Na}$ and $\mathrm{N}$ did not show statistically significant difference (Table 3). Statistically significant difference was observed through one way ANOVA in the comparison of soils existing under Classes 1, 2 and 3 Prosopis plant canopies in relation to $\mathrm{pH}$ and $\mathrm{EC}(F=6.56$, $P=0.01$ and $F=4.77, P=0.01$ respectively at $\alpha=0.05$ ). Further, Student's t-Test (one tailed) revealed that soils found under Class 3 Prosopis plant canopies were statis- 
tically significantly different from soils found under Classes 1 and 2 Prosopis plant canopies with respect to $\mathrm{pH}$ and EC (Table 4), while soils existing under Classes 1 and 2 Prosopis plant canopies were not statistically significantly different.

\section{DISCUSSION}

Studies similar to the current research have indicated that Prosopis plants significantly modify the characteristics of soils on which they grow (e.g. $[5,17])$. Such studies showed that increased soil nutrient content (e.g. soil organic matter, $\mathrm{Ca}, \mathrm{Mg}, \mathrm{K}$ and $\mathrm{Na}$ and $\mathrm{N}$ ) and lower values of $\mathrm{pH}$ levels are normally associated with soils found under the canopies of Prosopis plants compared to the inter-canopy areas in arid and semi-arid environments
$[1,17]$. However, the $\mathrm{Ca}, \mathrm{Mg}, \mathrm{K}, \mathrm{Na}$ and $\mathrm{N}$ in the soils were low and the soils under Prosopis plant canopies and the inter-canopy areas were not statistically significantly different in relation to the afore-mentioned soil nutrients in the study area. This suggested that Prosopis plants did not significantly enhance the $\mathrm{Ca}, \mathrm{Mg}, \mathrm{K}, \mathrm{Na}$ and $\mathrm{N}$ content of soils in the study area.

The general pattern in the soil $\mathrm{pH}$ indicated significant lower $\mathrm{pH}$ levels at $0-20 \mathrm{~cm}$ soil depth as compared to $60-80 \mathrm{~cm}$ soil depth. Prosopis plants growing in the study area produced considerable amount of litter fall as it is usually the case in other habitats where Prosopis plants grow. For instance, [21] observed that a 4 to 6 year old Prosopis juliflorast and produced 5 to 8 tonnes per hector per year of dry leaf litter, while 8 year old Pro-

Table 1. Selected soil properties under Prosopis plant canopies and the spaces between tree canopies.

\begin{tabular}{|c|c|c|c|c|c|c|c|c|}
\hline Sampling Site & $\mathrm{pH}$ & $\mathrm{EC}(\mu \mathrm{S} / \mathrm{cm})$ & $\mathrm{Ca}(\mathrm{cmol} / \mathrm{kg})$ & $\mathrm{Mg}(\mathrm{cmol} / \mathrm{kg})$ & $\mathrm{K}(\mathrm{cmol} / \mathrm{kg})$ & $\mathrm{Na}(\mathrm{cmol} / \mathrm{kg})$ & $\mathrm{C}(\%)$ & $\mathrm{N}(\%)$ \\
\hline Under Canopy 0 - $20 \mathrm{~cm}$ & $7.75 \pm 0.44$ & $308.70 \pm 10.21$ & $1.11 \pm 0.03$ & $0.62 \pm 0.01$ & $0.11 \pm 0.03$ & $0.04 \pm 0.01$ & $0.344 \pm 0.041$ & $0.066 \pm 0.002$ \\
\hline Inter-canopy $0-20 \mathrm{~cm}$ & $8.11 \pm 0.43$ & $223.72 \pm 12.16$ & $1.17 \pm 0.07$ & $0.17 \pm 0.01$ & $0.10 \pm 0.01$ & $0.05 \pm 0.01$ & $0.340 \pm 0.022$ & $0.043 \pm 0.003$ \\
\hline Inter-canopy $60-80 \mathrm{~cm}$ & $8.19 \pm 2.14$ & $212.72 \pm 9.43$ & $1.21 \pm 0.02$ & $0.16 \pm 0.02$ & $0.09 \pm 0.03$ & $0.07 \pm 0.01$ & $0.500 \pm 0.015$ & $0.045 \pm 0.002$ \\
\hline
\end{tabular}

Table 2. Selected soil properties under canopies of three categories of Prosopis plants.

\begin{tabular}{ccccccccc}
\hline Sampling Site & $\mathrm{pH}$ & $\mathrm{EC}\left(\mu \mathrm{S} \cdot \mathrm{cm}^{-1}\right)$ & $\mathrm{Ca}\left(\mathrm{cmol} \cdot \mathrm{kg}^{-1}\right)$ & $\mathrm{Mg}\left(\mathrm{cmol} \cdot \mathrm{kg}^{-1}\right)$ & $\mathrm{K}\left(\mathrm{cmol} \cdot \mathrm{kg}^{-1}\right)$ & $\mathrm{Na}\left(\mathrm{cmol} \cdot \mathrm{kg}^{-1}\right)$ & $\mathrm{C}(\%)$ & $\mathrm{N}(\%)$ \\
\hline Class 1 & $8.28 \pm 0.27$ & $158.48 \pm 13.54$ & $1.20 \pm 0.42$ & $0.12 \pm 0.06$ & $0.12 \pm 0.05$ & $0.15 \pm 0.01$ & $0.455 \pm 0.023$ & $0.058 \pm 0.001$ \\
Class 2 & $8.19 \pm 0.22$ & $170.72 \pm 9.47$ & $1.11 \pm 0.37$ & $0.11 \pm 0.05$ & $0.12 \pm 0.04$ & $0.14 \pm 0.01$ & $0.461 \pm 0.012$ & $0.080 \pm 0.003$ \\
Class 3 & $8.09 \pm 0.20$ & $218.30 \pm 10.23$ & $1.29 \pm 0.44$ & $0.13 \pm 0.05$ & $0.15 \pm 0.06$ & $0.15 \pm 0.01$ & $0.572 \pm 0.014$ & $0.053 \pm 0.001$ \\
\hline
\end{tabular}

Table 3. Comparisons (t-Test $P$-values) of soil properties in the study area.

\begin{tabular}{|c|c|c|c|c|c|c|c|c|c|}
\hline \multicolumn{2}{|c|}{ Sampling sites } & \multirow{2}{*}{$\frac{\mathrm{pH}}{<0.001^{*}}$} & \multirow{2}{*}{$\frac{\mathrm{EC}}{<0.001^{*}}$} & \multirow{2}{*}{$\frac{\mathrm{Ca}}{0.28}$} & \multirow{2}{*}{$\begin{array}{c}\mathrm{Mg} \\
0.27\end{array}$} & \multirow{2}{*}{$\frac{\mathrm{K}}{0.22}$} & \multirow{2}{*}{$\begin{array}{c}\mathrm{Na} \\
0.05^{*}\end{array}$} & \multirow{2}{*}{$\begin{array}{c}\mathrm{N} \\
0.11\end{array}$} & \multirow{2}{*}{$\frac{\mathrm{C}}{0.05^{*}}$} \\
\hline & $60-80 \mathrm{~cm}$ canopy & & & & & & & & \\
\hline \multirow[t]{2}{*}{$0-20 \mathrm{~cm}$ canopy } & $0-20 \mathrm{~cm}$ inter-canopy & $<0.001^{*}$ & $0.020^{*}$ & 0.69 & 0.87 & 0.42 & 0.67 & 0.06 & 0.95 \\
\hline & $60-80 \mathrm{~cm}$ inter-canopy & $<0.001^{*}$ & $0.021^{*}$ & 0.59 & 0.91 & 0.13 & 0.13 & 0.19 & 0.07 \\
\hline \multirow{2}{*}{$60-80 \mathrm{~cm}$ canopy } & $0-20 \mathrm{~cm}$ inter-canopy & $<0.001^{*}$ & 0.610 & 0.47 & 0.34 & 0.63 & 0.07 & 0.08 & $0.04^{*}$ \\
\hline & $60-80 \mathrm{~cm}$ inter-canopy & 0.861 & 0.472 & 0.42 & 0.26 & 0.77 & 0.78 & 0.09 & 0.71 \\
\hline $\begin{array}{c}0-20 \mathrm{~cm} \\
\text { inter-canopy }\end{array}$ & $60-80 \mathrm{~cm}$ inter-canopy & $<0.001^{*}$ & 0.871 & 0.92 & 0.80 & 0.13 & 0.20 & 0.60 & $0.05^{*}$ \\
\hline
\end{tabular}

*The mean difference is significant at $\alpha=0.05$.

Table 4. Comparison (t-Test $P$-values) of soils under canopies of three categories of Prosopis plants.

\begin{tabular}{|c|c|c|c|c|c|c|c|c|c|}
\hline & & $\mathrm{pH}$ & $\mathrm{EC}$ & $\mathrm{Na}$ & $\mathrm{K}$ & $\mathrm{Ca}$ & $\mathrm{Mg}$ & $\mathrm{N}$ & $\mathrm{C}$ \\
\hline \multirow[t]{2}{*}{ Class 1} & Class 2 & 0.176 & 0.395 & 0.371 & 0.863 & 0.453 & 0.877 & 0.532 & 0.937 \\
\hline & Class 3 & $0.004^{*}$ & $0.004^{*}$ & 0.976 & 0.105 & 0.411 & 0.415 & 0.963 & 0.126 \\
\hline Class 2 & Class 3 & 0.079 & $0.013^{*}$ & 0.397 & 0.134 & 0.112 & 0.311 & 0.423 & 0.121 \\
\hline
\end{tabular}

*The mean difference is significant at the $\alpha=0.05$ level. 
sopis juliflora stand produced 7.4 tonnes per hector per year of dry leaf litter [17] in India. The dominant tree forms of Prosopis plants that grow in the study area are prostrate and decumbent, and these types of plant growth promote the accumulation of tree litter under the trees. The accumulation of tree litter under Prosopis plant canopies appeared to have led to the establishment of the conditions that promoted reduction in soil $\mathrm{pH}$, such as low evaporation rates and initiation of biological activeties [20,21]. Additionally, the accumulation of tree litter under Prosopis plant canopies promoted the accumulation of soil organic carbon in soil existing under Prosopis plant canopies. Prosopis plants evidently enhanced soil organic carbon content and also influenced the soil $\mathrm{pH}$ particularly under Prosopis plant canopies.

Tree growth and canopy development normally lead to increase in the period of nutrient accumulation and improvement in understory soil conditions $[8,9]$. For this reason, statistically significant differences in the soils existing under the canopies of Classes 1, 2 and 3 Prosopis plants in relation to the selected soil properties was expected. On the contrary, no statistically significant difference in the soils existing under the canopies of Classes 1, 2 and 3 Prosopis plants in relation to soil organic carbon, $\mathrm{Ca}, \mathrm{Mg}, \mathrm{K}, \mathrm{Na}$ and $\mathrm{N}$ was observed, suggesting that the influence of height and canopy size of Prosopis plants on the soil properties was not significant. Statistically significant different observed between soils found under Class 3 Prosopis plant canopies and soils found under Classes 1 and 2 Prosopis plant canopies in relation to soil $\mathrm{pH}$ and EC indicated that mature Prosopis plants influenced the understory soil $\mathrm{pH}$ and $\mathrm{EC}$.

\section{CONCLUSION}

This study specifically tested the assumptions that Prosopis plants significantly enhance the nutrient content and improve the condition of soils in the Kalahari area and that the height and canopy size of Prosopis plants affect the interactions between Prosopis plants and the soils. Empirical evidence from this study showed that Prosopis plants enhanced soil organic carbon content and also influenced soil $\mathrm{pH}$ and EC in soils existing underProsopis plant canopies. In addition, the height and canopy size of Prosopis plant affected the interactions between Prosopis plants and the soils.

\section{REFERENCES}

[1] Pasiecznik, N.M. (2001) The Prosopis juliflora-Prosopis pallid complex: A momograph. HDRA, Coventry.

[2] Burkart, A. (1976) A monograph of the genus Prosopis (Leguminosae sub-fam. Mimosoideae): Part 1. and Part 2. Catalogue of the recognized species of Prosopis. Journal of the Arnold Arboretum, 57, 219-249.
[3] Felker, P. and Clark, P.R. (1981) Rooting of mesquite (Prosopis) cuttings. Journal of Range Management, 34, 466-468. doi:10.2307/3898099

[4] Schlesinger, W.H., Raikes, J.A., Hartley, A.E. and Cross, A.F. (1996) On the spatial pattern of soil nutrients in desert ecosystem. Ecology, 77, 364-374. doi: $10.2307 / 2265615$

[5] Geesing, D., Felker, P. and Bingham, R.L. (2000) Influence of mesquite (Prosopis glandulosa) on soil nitrogen and carbon development: Implications for global carbon sequestration. Journal of Arid Environments, 46, 157-180. doi:10.1006/jare.2000.0661

[6] Robinson, D. (1994) The responses of plants to non-uniform supplies of nutrients. New Phytologist, 127, 635-674. doi:10.1111/j.1469-8137.1994.tb02969.x

[7] Maestre, F.T. and Reynolds, J.F. (2006) Small-scale spatial heterogeneity in the vertical distribution of soil nutriaents has limited effects on the growth and development of Prosopis glandulosa seedlings. Plant Ecology, 183, 65-75. doi:10.1007/s11258-005-9007-1

[8] Ludwig, J.A., Reynolds, J.F. and Whitson, P.D. (1975) Size-biomass relations of several Chihuahuan Desert shrubs. American Midland Naturalist, 94, 451-461. doi: $10.2307 / 2424437$

[9] Reynolds, J.F., Virgia, R.A., Kemp, P.R., De Soyza, A.G. and Tremmel, D.C. (1999) Impact of drought on desert shrubs: Effects of seasonality and degree of resource island development. Ecological Monographs, 69, 69-106. doi:10.1890/0012-9615(1999)069[0069:IODODS]2.0.CO ;2

[10] Timberlake, J. (1980) Handbook of Botswana Acacias. Ministry of Agriculture, Gaborone.

[11] Lancaster, I.N. (1978) The pans of Southern Kalahari, Botswana. Geographical Journal, 144, 81-98. doi: $10.2307 / 634651$

[12] Shaw, P.A. and Thomas, S.G. (1997) Pans, playas and salt lakes. In: Thomas, D.S.G., Ed., Arid Zone Geomorphology; Process, Form and Change in Drylands. John Wiley and Sons, New York, 293-312.

[13] Muzila, M., Setshogo, M.P., Moseki, B. and Morapedi, R. (2011) An assessment of Prosopis L. in the Bokspits area, south-western Botswana, based on morphology. The African Journal of Plant Science and Biotechnology, 5, 7580.

[14] Bhalotra, Y.P.R. (1985) Rainfall maps of Botswana. Department of Meteorological Services, Gaborone.

[15] Sonnevelt, C. and vandenEnde, J. (1971) Soil analysis by means of a 1:2 volume extract. Plant Soil, 35, 505-506. doi:10.1007/BF01372683

[16] Chhabra, R., Pleysier, J. and Cremers, A. (1975) The measurement of the cation exchange capacity and exchangeable cations in soils: A new method. Proceedings of International Clay Conference, Mexico City, 439-449.

[17] Garg, V.K. (1998) Interaction of tree crops with a sodic soil environment: Potential for rehabilitation of degraded environments. Land Degradation a Development, 9, 81-93. doi:10.1002/(SICI)1099-145X(199801/02)9:1<81::AID-L $\underline{\mathrm{DR} 267>3.0 . \mathrm{CO} ; 2-\mathrm{R}}$ 
[18] Skarpe, C. (1986) Plant community structure in relation to grazing and environmental changes along a North South transect in Western Kalahari. Vegetatio, 68, 3-18.

[19] Vanderpost, C., Ringrose, S., Matheson, W. and Arntzen, J. (2011) Satellite based long-term assessment of rangeland condition in semi-arid areas: An example from Botswana. Journal of Arid Environments, 75, 383-389. doi:10.1016/j.jaridenv.2010.11.002

[20] Bhojvaid, P.P., Timmer, V.R. and Singh, G. (1996) Reclaiming sodic soils for wheat production by Prosopi juli- flora (Swartz) DC afforestation in India. Agroforestry Systems, 34, 139-150. doi:10.1007/BF00148158

[21] Singh. G. (1996) The role of Prosopis in reclaiming high$\mathrm{pH}$ soils and in meeting firewood and forage needs of small farmers. In: Felker, P. and Moss, J., Eds., Prosopis: Semiarid Fuelwood and Forage Tree; Building Consensus for the Disenfranchised, Center for Semi-Arid Forest Resources, Kingsville, 4.21-4.34. 